\title{
Inventory Turnover Of Fortune 500 Manufacturing Companies After 2001 And Its Relationship To Net Earning
}

Edward Chu, California State University, Dominguez Hills

\begin{abstract}
In order to determine whether the largest United States manufacturers had changed their inventory policies after the terrorist attacks in 2001, averages of inventory turnover ratios of 157 manufacturing companies in the 2002 Fortune 500 list (2001 ranking) calculated for the 3-year pre-2001 (1998 to 2000) period were compared with that of the 3-year post-2001 (2002 to 2004) period in aggregate, by the 2001 Fortune 500 ranking and by industry using paired-samples $t$ tests. Overall results indicate that there is no significant change in inventory turnover before and after 2001. This is in contrast to the significant inventory reduction found in the two decades before 2001 as reported in previous literature. However, the finding in this study that inventory turnover is not related to net earning is consistent with other studies. Possible explanations and areas for future research are also discussed.
\end{abstract}

Keywords: inventory turnover; Fortune 500; manufacturing companies; net earning

\section{INTRODUCTION}

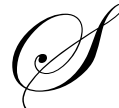

ince the early 80s, U.S. manufacturing companies have been embracing the Just-In-Time (JIT) philosophy of inventory reduction. Studies have shown that their efforts have generally been quite successful. For example, using data published by the U.S. Census Bureau, Rajagopalan and Malhotra (2001) studied trends in raw materials, work-in-process and finished goods inventory ratios during the period 1961 to 1994 in 20 manufacturing industry sectors and the total U.S. manufacturing sector to determine whether a significant decrease was seen in these ratios. Overall, the analysis provides an encouraging but somewhat mixed picture about the results of U.S. manufacturing inventory-reduction efforts. In a more recent study, Chen, Frank and Wu (2005) examined the inventories of publicly traded American manufacturing companies between 1981 and 2000. They found the median of inventory holding periods were reduced from 96 days to 81 days and the average rate of inventory reduction was about $2 \%$ per year. The greatest reduction was found for work-in-process inventory, which declined by about $6 \%$ per year, while finished goods inventory did not decline.

However, results of the above studies were based on inventory information of U.S. manufacturing companies before the terrorist attacks on September 11, 2001 (9-11). It is doubtful whether companies continue their inventory reduction efforts in midst of increased uncertainties in their supply chains after 9-11. Phillips (2001) cautions that as a result of the attacks, shippers will face higher costs and fewer options, and some may be forced to redesign their just-in-time supply chains and distribution systems. Sheffi (2001) predicts the impacts of the new era will challenge supply chain managers to adjust relations with suppliers and customers, contend with transportation difficulties and amend inventory management strategies. Therefore, it is likely that U.S. manufacturing companies may have reversed their inventory management strategy from just-in-time to just-in-case to deal with the heightened uncertainties. The main purpose of this research study is to determine whether this is true for the Fortune 500 manufacturing companies which are most likely to be involved and affected by global logistics changes. Another objective is to determine the significance of inventory turnover ratio on a manufacturing firm's net earning. 


\section{LITERATURE REVIEW}

Inventory turnover ratio is commonly used in JIT research because it is a simple and accurate measure of inventory management performance, which is not dramatically affected by price changes in raw materials, component parts and finished goods (Billesbach \& Hayen, 1994). Huson and Nanda (1995) concluded that, between 1980 and 1990, inventory turnover improved by $23.7 \%$ for firms adopting JIT compared to only $7.7 \%$ for nonadopting firms. Chang and Lee (1995) also indicated that JIT firms achieved higher inventory turnover than non-JIT firms from 1984 to 1990 . Because higher inventory turnover is often associated with JIT adoption, Kinney and Wempe (2002) actually used greater improvement in inventory turnover as an indicator to identify JIT adopters. Alternatively, instead of comparing inventory turnover of JIT and non-JIT firms, Vergin (1998) analyzed the changes in inventory turnover ratios, for the years 1986 through 1995, of 427 firms from the Fortune 500 industrial corporations (the 1994 list) and found that the improvement in inventory turnover averaged about $1.5 \%$ per year over the 1986-1995 decade. This research study extends the Vergin (1998) study to cover years 1998 through 2006 using the 2002 Fortune 500 list (2001 ranking) of manufacturing firms to determine any significant change in inventory turnover before and after the terrorist attacks in 2001.

\section{DATA AND RESEARCH METHODOLOGY}

Initially, 180 manufacturing firms were identified in the 2002 Fortune 500 list (2001 ranking) with the first 2-digit Standard Industrial Classification (SIC) codes between 20 and 39 (Division D-Manufacturing). However, only 157 of these manufacturing firms had complete data available from 1998 to 2006 to be used in this study. Table 1 shows the composition of the 157 manufacturing companies studied.

Table 1: Composition Of Manufacturing Companies In The Studied Sample From The 2002 Fortune 500 List

\begin{tabular}{|c|l|c|c|}
\hline SIC Code & \multicolumn{1}{|c|}{ SIC Code Description } & Number of Firms & $\%$ \\
\hline 35 & Industrial machinery and computers (Computer) & 29 & 18.47 \\
\hline 28 & Chemicals and allied products (Chemical) & 24 & 15.29 \\
\hline 20 & Food and kindred products (Food) & 19 & 12.10 \\
\hline 37 & Transportation equipment (Transport) & 17 & 10.83 \\
\hline 36 & Electronic and electrical equipment (Electronic) & 9 & 8.28 \\
\hline 38 & Instruments and related products (Instrument) & 8 & 5.73 \\
\hline 29 & Petroleum and coal products (Petroleum) & 7 & 5.10 \\
\hline 26 & Paper and allied products (Paper) & 5 & 4.46 \\
\hline 33 & Primary metal industries (P-Metal) & 4 & 3.18 \\
\hline 25 & Furniture and fixtures (Furniture) & 4 & 2.55 \\
\hline 27 & Printing and publishing (Printing) & 4 & 2.55 \\
\hline 30 & Rubber and plastic products (Rubber) & 4 & 2.55 \\
\hline 34 & Fabricated metal products (F-Metal) & 3 & 2.55 \\
\hline 23 & Apparel and textile products (Apparel) & 3 & 1.91 \\
\hline 32 & Stone, clay, and glass products (Stone) & 2 & 1.91 \\
\hline 24 & Lumber and wood products (Lumber) & 1 & 1.27 \\
\hline 22 & Textile mill products (Textile) & 1 & 0.64 \\
\hline 39 & Miscellaneous Manufacturing (Misc) & 157 & 0.64 \\
\hline & Total: & & 100.00 \\
\hline
\end{tabular}

For each of the 157 manufacturing companies studied, cost of goods sold and net earning figures were obtained from annual income statements while year-end total inventory figures were obtained from balance sheets for years 1998 through 2006. Then, for each year, each company's annual inventory turnover ratio was calculated by dividing annual cost of goods sold by year-end total inventory as in Vergin (1998). In order to determine any significant change in inventory turnover before and after the terrorist attacks in 2001 and to provide smoothing for any one-year anomalies, averages of inventory turnover ratios of manufacturing companies calculated for the 3-year pre-2001 (1998 to 2000) period were compared with that of the 3-year post-2001 (2002 to 2004) period in aggregate, 
by the 2001 Fortune 500 ranking and by industry using paired-samples t-tests which required that the differences had a normal distribution. This requirement was satisfied by performing the 1-sample Kolmogorov-Smirnov (K-S) test on all 157 average differences yielding the K-S Z value of 4.106 which was statistically significant at the 0.01 (2-tailed) level. In addition, for years 1998 through 2006, with net earning as the dependent variable, the significance of inventory turnover ratio was determined in aggregate, by the 2001 Fortune 500 ranking and by industry using simple linear regressions. The studies by ranking were performed by classifying the 157 firms into 3 groups based on their 2001 Fortune 500 rankings - T (top third, 52 firms), M (middle third, 52 firms) and B (bottom third, 53 firms). The studies by industry were performed on firms in each of the 162 -digit SIC codes which had at least two firms. Table 2 indicates the average 2001 Fortune 500 rankings of manufacturing firms studied in different groupings.

Table 2: Average 2001 Fortune 500 Rankings Of Firms Studied

\begin{tabular}{|c|l|c|c|c|c|}
\hline SIC Code & \multicolumn{1}{|c|}{ SIC Code Description } & $\begin{array}{c}\text { Number } \\
\text { of Firms }\end{array}$ & $\begin{array}{c}\mathbf{2 0 0 1} \\
\text { Ave Rank }\end{array}$ & $\begin{array}{c}\mathbf{2 0 0 1} \text { S.D. of Rank } \\
\text { 2001 } \\
\text { C.V. }\end{array}$ \\
\hline T & Top third in the 2001 ranking & 52 & 82.80 & 46.74 & 0.56 \\
\hline 29 & Petroleum and coal products & 8 & 152.41 & 127.53 & 0.84 \\
\hline 24 & Lumber and wood products & 2 & 186.50 & 47.85 & 0.26 \\
\hline 37 & Transportation equipment & 17 & 199.36 & 162.30 & 0.81 \\
\hline 20 & Food and kindred products & 19 & 205.89 & 118.59 & 0.58 \\
\hline 28 & Chemicals and allied products & 24 & 227.24 & 141.35 & 0.62 \\
\hline 36 & Electronic and electrical equipment & 13 & 246.07 & 146.35 & 0.59 \\
\hline All & All 18 SIC codes & 157 & 253.06 & 143.70 & 0.57 \\
\hline M & Middle third in the 2001 ranking & 52 & 259.49 & 53.27 & 0.21 \\
\hline 38 & Instruments and related products & 9 & 260.02 & 119.71 & 0.46 \\
\hline 25 & Furniture and fixtures & 4 & 274.19 & 142.90 & 0.52 \\
\hline 35 & Industrial machinery and computers & 29 & 275.27 & 136.89 & 0.50 \\
\hline 26 & Paper and allied products & 7 & 275.94 & 163.85 & 0.59 \\
\hline 30 & Rubber and plastic products & 4 & 306.57 & 142.81 & 0.47 \\
\hline 34 & Fabricated metal products & 4 & 322.28 & 71.54 & 0.22 \\
\hline 33 & Primary metal industries & 5 & 336.51 & 123.96 & 0.37 \\
\hline 27 & Printing and publishing & 4 & 367.75 & 81.34 & 0.22 \\
\hline 32 & Stone, clay, and glass products & 3 & 374.96 & 74.67 & 0.20 \\
\hline 23 & Apparel and textile products & 3 & 388.40 & 48.99 & 0.13 \\
\hline B & Bottom third in the 2001 ranking & 53 & 413.30 & 46.23 & 0.11 \\
\hline
\end{tabular}

Ave $=$ Average, S.D.=Standard Deviation, C.V.=Coefficient of Variation

\section{RESULTS AND ANALYSIS OF INVENTORY TURNOVER DIFFERENCES}

Table 3 shows the correlations and paired-samples t-test results of 1998-2000 average inventory turnover ratios (A1) and 2002-2004 average inventory turnover ratios (A2). The correlations between A1 and A2 are all positive and are significant in almost all groupings indicating that manufacturing firms which have higher/lower inventory turnovers continue to have higher/lower inventory turnovers. However, only two industries, the petroleum and coal products industry (SIC code 29) and the fabricated metal products industry (SIC code 34), exhibit significant improvements between averages of inventory turnover ratios for the 3-year pre-2001 (1998 to 2000) period and that of the 3-year post-2001 (2002 to 2004) period. 
Table 3: Correlations And Paired-Samples T-Test Results Of 1998-2000 Average Inventory Turnover Ratios (A1) And 2002-2004 Average Inventory Turnover Ratios (A2)

\begin{tabular}{|c|c|c|c|c|c|c|c|}
\hline SIC Code & $\begin{array}{c}\text { SIC Code } \\
\text { Description }\end{array}$ & $\begin{array}{l}\text { Number } \\
\text { of Firms }\end{array}$ & $\begin{array}{c}\text { Average of } \\
\text { A1 }\end{array}$ & $\begin{array}{c}\text { Average of } \\
\text { A2 }\end{array}$ & $\begin{array}{l}\text { Correl of } \\
\text { A1 \& A2 }\end{array}$ & $\begin{array}{l}\text { Ave Ave } \\
\text { A2 - A1 }\end{array}$ & $\begin{array}{c}\mathbf{T} \\
\text { Value }\end{array}$ \\
\hline All & All 18 SICs & 157 & 9.03 & 9.39 & $0.834 * *$ & 0.36 & 0.606 \\
\hline $\mathrm{T}$ & Top $3^{\text {rd }}$ & 52 & 8.60 & 10.15 & $0.920 * *$ & 1.55 & 1.599 \\
\hline $\mathrm{M}$ & Middle $3^{\text {rd }}$ & 52 & 10.66 & 9.70 & $0.947 * *$ & -0.96 & -0.656 \\
\hline $\mathrm{B}$ & Bottom $3^{\text {rd }}$ & 53 & 7.86 & 8.35 & $0.966 * *$ & 0.49 & 1.931 \\
\hline 35 & Computer & 29 & 13.76 & 12.93 & $0.803 * *$ & -0.83 & 0.264 \\
\hline 28 & Chemical & 24 & 4.65 & 4.94 & $0.894 * *$ & 0.29 & 1.128 \\
\hline 20 & Food & 19 & 8.85 & 8.80 & $0.948 * *$ & -0.05 & -0.125 \\
\hline 37 & Transport & 17 & 9.15 & 10.13 & $0.871 * *$ & 0.98 & 1.565 \\
\hline 36 & Electronic & 13 & 6.26 & 6.41 & 0.311 & 0.15 & 0.226 \\
\hline 38 & Instrument & 9 & 3.91 & 4.60 & $0.918 * *$ & 0.69 & 2.144 \\
\hline 29 & Petroleum & 8 & 15.54 & 18.33 & $0.819 *$ & $2.79 *$ & 2.478 \\
\hline 26 & Paper & 7 & 7.36 & 7.79 & $0.762 *$ & 0.43 & 1.100 \\
\hline 33 & P-Metal & 5 & 6.17 & 6.72 & $0.922 *$ & 0.55 & 1.755 \\
\hline 30 & Rubber & 4 & 5.36 & 5.41 & $0.957 *$ & 0.05 & 0.122 \\
\hline 34 & F-Metal & 4 & 3.71 & 4.78 & $0.986 *$ & $1.07 *$ & 4.991 \\
\hline 25 & Furniture & 4 & 17.24 & 17.60 & $0.959 *$ & 0.36 & 0.271 \\
\hline 27 & Printing & 4 & 24.40 & 26.79 & $0.980 *$ & 2.39 & 1.040 \\
\hline 23 & Apparel & 3 & 3.73 & 4.30 & 0.903 & 0.57 & 1.818 \\
\hline 32 & Stone & 3 & 8.00 & 8.46 & 0.969 & 0.46 & 0.812 \\
\hline 24 & Lumber & 2 & 6.40 & 6.92 & $1.000 * *$ & 0.52 & 0.690 \\
\hline
\end{tabular}

Correl=Correlation,

$*$ and $* *$ denote statistical significance at $5 \%$ and $1 \%$ levels (2-tailed), respectively

\section{RESULTS AND ANALYSIS OF RELATIONSHIP BETWEEN INVENTORY TURNOVER RATIO AND NET EARNING}

For years 1998 through 2006, with net earning as the dependent variable, the significance of inventory turnover ratio was determined in aggregate, by the 2001 Fortune 500 ranking and by industry using simple linear regressions. Tables 4 and 5, respectively, show the 1998-2006 average inventory turnover ratios and average net earnings of manufacturing companies studied in various groupings.

Table 4 indicates that companies in the printing and publishing industry (SIC code 27) has the highest average inventory turnover ratio of 25.79 while the industrial machinery and computer industry (SIC code 35) has the most inventory turnover variation (coefficient variation of 2.33) among all industries. On the other hand, interestingly, the apparel and textile products industry (SIC code 23) has both the smallest average inventory turnover ratio of 4.12 and the least inventory turnover variation (coefficient variation of 0.13 ). Table 5 illustrates that despite there are substantial disparities in the average net earnings between and within industries, only the stone, clay and glass products industry (SIC code 32) has a negative average net earning in years 1998 through 2006. Table 6.

The regression results of 1998-2006 inventory turnover ratios and 1998-2006 net earnings are given in 
Table 4: 1998-2006 Average Inventory Turnover Ratios

\begin{tabular}{|c|l|c|c|c|c|}
\hline SIC Code & \multicolumn{1}{|c|}{ SIC Code Description } & $\begin{array}{c}\text { Number } \\
\text { of Firms }\end{array}$ & $\begin{array}{c}\mathbf{9 8 - 0 6} \\
\text { Ave Invent. } \\
\text { Turn. }\end{array}$ & $\begin{array}{c}\text { 98-06 } \\
\text { S.D. Invent. } \\
\text { Turn. }\end{array}$ & $\begin{array}{c}\text { 98-06 } \\
\text { C.V. }\end{array}$ \\
\hline 27 & Printing and publishing & 4 & 25.79 & 15.41 & 0.60 \\
\hline 29 & Petroleum and coal products & 8 & 17.66 & 6.82 & 0.39 \\
\hline 25 & Furniture and fixtures & 4 & 17.43 & 8.44 & 0.48 \\
\hline 35 & Industrial machinery and computers & 29 & 13.99 & 32.62 & 2.33 \\
\hline 37 & Transportation equipment & 17 & 10.48 & 5.77 & 0.55 \\
\hline M & Middle third in the 2001 ranking & 52 & 10.44 & 22.52 & 2.16 \\
\hline T & Top third in the 2001 ranking & 52 & 9.87 & 11.24 & 1.14 \\
\hline All & All 18 SIC codes & 157 & 9.45 & 15.04 & 1.59 \\
\hline 20 & Food and kindred products & 19 & 8.83 & 5.29 & 0.60 \\
\hline 32 & Stone, clay, and glass products & 3 & 8.49 & 2.97 & 0.35 \\
\hline B & Bottom third in the 2001 ranking & 53 & 8.06 & 6.73 & 0.84 \\
\hline 26 & Paper and allied products & 7 & 7.74 & 1.62 & 0.21 \\
\hline 24 & Lumber and wood products & 2 & 6.90 & 0.94 & 0.14 \\
\hline 33 & Primary metal industries & 5 & 6.63 & 2.92 & 0.44 \\
\hline 36 & Electronic and electrical equipment & 13 & 6.19 & 2.19 & 0.35 \\
\hline 30 & Rubber and plastic products & 4 & 5.44 & 1.43 & 0.26 \\
\hline 38 & Instruments and related products & 9 & 5.24 & 4.13 & 0.79 \\
\hline 28 & Chemicals and allied products & 24 & 4.94 & 2.97 & 0.60 \\
\hline 34 & Fabricated metal products & 4 & 4.68 & 1.54 & 0.33 \\
\hline 23 & Apparel and textile products & 3 & 4.12 & 0.53 & 0.13 \\
\hline
\end{tabular}

Ave $=$ Average, S.D.=Standard Deviation, C.V.=Coefficient of Variation

Table 5: 1998-2006 Average Net Earnings

\begin{tabular}{|c|l|c|c|c|c|}
\hline SIC Code & \multicolumn{1}{|c|}{ SIC Code Description } & $\begin{array}{c}\text { Number } \\
\text { of Firms }\end{array}$ & $\begin{array}{c}\mathbf{9 8 - 0 6} \\
\text { Ave Net } \\
\text { Earning (\$M) }\end{array}$ & $\begin{array}{c}\text { 98-06 } \\
\text { S.D. of } \\
\text { Net Earning }\end{array}$ & $\begin{array}{c}\text { 98-06 } \\
\text { C.V. }\end{array}$ \\
\hline 29 & Petroleum and coal products & 8 & 4111.76 & 7713.05 & 1.88 \\
\hline T & Top third in the 2001 ranking & 52 & 2673.65 & 4701.55 & 1.76 \\
\hline 28 & Chemicals and allied products & 24 & 2019.71 & 2652.73 & 1.31 \\
\hline 20 & Food and kindred products & 19 & 1299.09 & 2200.33 & 1.69 \\
\hline All & All 18 SIC codes & 157 & 1115.27 & 3366.30 & 3.02 \\
\hline 35 & Industrial machinery and computers & 29 & 1103.79 & 2069.40 & 1.87 \\
\hline 36 & Electronic and electrical equipment & 13 & 893.52 & 6438.40 & 7.21 \\
\hline 38 & Instruments and related products & 9 & 757.49 & 912.28 & 1.20 \\
\hline M & Middle third in the 2001 ranking & 52 & 640.79 & 1248.65 & 1.95 \\
\hline 37 & Transportation equipment & 17 & 598.90 & 2652.14 & 4.43 \\
\hline 24 & Lumber and wood products & 2 & 591.36 & 284.32 & 0.48 \\
\hline 27 & Printing and publishing & 4 & 550.92 & 453.77 & 0.82 \\
\hline 34 & Fabricated metal products & 4 & 349.90 & 610.54 & 1.74 \\
\hline 26 & Paper and allied products & 7 & 344.52 & 625.74 & 1.82 \\
\hline 25 & Furniture and fixtures & 4 & 225.36 & 414.26 & 1.84 \\
\hline 23 & Apparel and textile products & 3 & 212.77 & 184.30 & 0.87 \\
\hline 33 & Primary metal industries & 5 & 206.86 & 1229.06 & 5.94 \\
\hline 30 & Rubber and plastic products & 4 & 130.65 & 577.77 & 4.42 \\
\hline B & Bottom third in the 2001 ranking & 53 & 57.85 & 2595.17 & 44.86 \\
\hline 32 & Stone, clay, and glass products & 3 & -343.55 & 1038.35 & -3.02 \\
\hline
\end{tabular}

Ave=Average, S.D. = Standard Deviation, C.V.=Coefficient of Variation 
Table 6: Regression Results Of 1998-2006 Inventory Turnover Ratios (X) And 1998-2006 Net Earnings (Y)

\begin{tabular}{|c|l|c|c|c|c|}
\hline SIC Code & \multicolumn{1}{|c|}{ SIC Code Description } & $\begin{array}{c}\text { Number } \\
\text { of Firms }\end{array}$ & $\begin{array}{c}\text { Number of } \\
\text { Pairs }\end{array}$ & $\begin{array}{c}\text { Beta for } \\
\text { Invent. Turn. }\end{array}$ & $\begin{array}{c}\text { T } \\
\text { Value }\end{array}$ \\
\hline All & All 18 SIC codes & 157 & 1493 & 0.003 & 0.108 \\
\hline T & Top third in the 2001 ranking & 52 & 493 & -0.012 & -0.265 \\
\hline M & Middle third in the 2001 ranking & 52 & 496 & -0.015 & -0.342 \\
\hline B & Bottom third in the 2001 ranking & 53 & 504 & -0.011 & -0.236 \\
\hline 35 & Industrial machinery and computers & 29 & 258 & -0.009 & -0.147 \\
\hline 28 & Chemicals and allied products & 24 & 215 & $-0.412^{* *}$ & -6.605 \\
\hline 20 & Food and kindred products & 19 & 171 & $-0.316^{* *}$ & -4.327 \\
\hline 37 & Transportation equipment & 17 & 159 & 0.027 & 0.344 \\
\hline 36 & Electronic and electrical equipment & 13 & 146 & $-0.199 *$ & -2.442 \\
\hline 38 & Instruments and related products & 9 & 88 & 0.008 & 0.070 \\
\hline 29 & Petroleum and coal products & 8 & 82 & 0.121 & 1.093 \\
\hline 26 & Paper and allied products & 7 & 65 & $-0.284 *$ & -2.348 \\
\hline 33 & Primary metal industries & 5 & 53 & $0.441^{* *}$ & 3.512 \\
\hline 30 & Rubber and plastic products & 4 & 42 & -0.242 & -1.578 \\
\hline 34 & Fabricated metal products & 4 & 40 & $-0.486^{* *}$ & -3.430 \\
\hline 25 & Furniture and fixtures & 4 & 37 & -0.030 & -0.176 \\
\hline 27 & Printing and publishing & 4 & 36 & -0.111 & -0.649 \\
\hline 23 & Apparel and textile products & 3 & 35 & -0.099 & -0.574 \\
\hline 32 & Stone, clay, and glass products & 3 & 26 & -0.127 & -0.626 \\
\hline 24 & Lumber and wood products & 2 & 18 & 0.229 & 0.939 \\
\hline
\end{tabular}

$*$ and $* *$ denote statistical significance at $5 \%$ and $1 \%$ levels (2-tailed), respectively

Table 6 indicates that in 5 industries, namely, food and kindred products (SIC code 20), paper and allied products (26), chemicals and allied products (28), fabricated metal products (34) and electronic and electrical equipment (36), the 1998-2006 inventory turnover ratios are negatively correlated with the 1998-2006 net earnings. Only in the primary metal industries (SIC code 33), they are positively correlated.

\section{CONCLUSIONS AND DISCUSSION}

In this study, averages of inventory turnover ratios of 157 manufacturing companies in the 2002 Fortune 500 list (2001 ranking) calculated for the 3-year pre-2001 (1998 to 2000) period were compared with that of the 3year post-2001 (2002 to 2004) period to determine whether the largest United States manufacturers had changed their inventory policies after the terrorist attacks in 2001. Results indicate that there is no significant change in inventory turnover before and after 2001 in aggregate and by the 2001 Fortune 500 ranking. Table 3 shows that only two industries, the petroleum and coal products industry (SIC code 29) and the fabricated metal products industry (SIC code 34), exhibit significant improvements between averages of inventory turnover ratios for the 3-year pre2001 (1998 to 2000) period and that of the 3-year post-2001 (2002 to 2004) period. This is in contrast to the significant inventory reduction found across industries in the two decades before 2001 (Chen, Frank \& Wu, 2005), thereby, suggesting that the largest U.S. manufacturers might have lessened their inventory reduction efforts in response to the disruptive events in 2001. However, in this study, total inventories are used in calculating the inventory turnover ratios and thus it is unknown which inventory component (raw material, work-in-process or finished goods) has been affected the most. Furthermore, results of this study are applicable only at the company level because inventory turnover ratio is determined only for the entire company and not for the different individual units in the company. Therefore, it is likely that while some units in a company lessen their inventory reduction efforts, other units continue their pursuits. The lack of significant improvement in inventory turnover of manufacturers found in this study may be the result of the increasing practice of vendor-managed inventory (VMI) which has a tendency to shift finished goods inventory storage from retailers to manufacturers. Another explanation is that after decades of reducing inventory, the return from further reduction is diminishing. This is evidenced by the finding in this study and other studies (Vergin, 1998; Vastag \& Whybark, 2005) that overall, inventory turnover ratio is not related to net earning. Table 6 shows that in five of the six industries, in which they are related, inventory 
turnover ratio is negatively related to net earning, thereby, suggesting that reducing inventory too much can also reduce net earning. This is consistent with the current belief that having inventory available where it is needed (being agile) is as important as simply reducing inventory (being lean) (Schonberger, 2003).

\section{SUGGESTIONS FOR FUTURE RESEARCH}

The above discussion implies that the finding in this study that the largest U.S. manufacturers have lessened their inventory reduction efforts in response to the disruptive events in 2001 should be considered as exploratory. The following are fruitful areas for future research to verify and strengthen the results:

1. Disaggregating the total inventory will allow the determination of the contributions of its components of raw material, work-in-process and finished goods inventory.

2. Conducting surveys and case studies of companies will provide insights into the inventory policies adopted by different companies and their individual units.

3. The dynamic relationships between manufacturers and retailers are different in different industries and, therefore, the importance of the practice of vendor-managed inventory (VMI) as a factor in determining a manufacturer's inventory policy is likely to be different and is worthwhile to investigate.

4. Similarly, the importance of being agile or being lean can be different in different industries. A manufacturer needs to be more agile in an uncertain environment while being lean is desirable in a stable environment. Guidelines for developing inventory policies which incorporate different mixes of responsiveness and leanness for different environments are needed.

5. In a broader sense, as Craighead et al. (2007) argue that supply chain disruptions are unavoidable and propose that a supply chain with the capability to proactively and/or reactively respond quickly and effectively to correcting the disruptive event is less likely to be severely affected, this study has focused on changing inventory policies and indicates that manufacturers have used additional inventories after the disruptive events in 2001 to achieve this objective. Studies are needed to discover whether companies have also used other means, such as protective capacity planning and better information-sharing, to manage risks in their supply chains and to compare the costs and benefits of different approaches.

\section{REFERENCES}

1. Billesbach, T.J. \& Hayen, R., Long-Term Impact of Just-In-Time on Inventory Performance Measures, Production and Inventory Management Journal, 35(1), 1994, 62-67.

2. Chang, D. \& Lee, S.M., Impact of JIT on Organizational Performance of U.S. Firms, International Journal of Production Research, 33(11), 1995, 3053-3068.

3. Chen, H., Frank, M.Z. \& Wu, O.Q., What Actually Happened to the Inventories of American Companies Between 1981 and 2000? Management Science, 51(7), 2005, 1015-1031.

4. $\quad$ Craighead, C.W., Blackhurst, J., Rungtusanatham, M.J. \& Hanfield, R.B., The Severity of Supply Chain Disruptions: Design Characteristics and Mitigation Capabilities, Decision Sciences, 38(1), 2007, 131-156.

5. Huson, M. \& Nanda, D., The Impact of Just-In-Time Manufacturing on Firm Performance in the U.S., Journal of Operations Management, 12(3-4), 1995, 297-310.

6. Kinney, M.R. \& Wempe, W.F., Further Evidence on the Extent and Origins of JIT's Profitability Effects, The Accounting Review, 77(1), 2002, 203-225.

7. $\quad$ Phillips, L.T., A Crisis of Security and Economics, Regulation, 24(4), 2001, 53-56.

8. Rajagopalan, S. \& Malhotra, A., Have U.S. Manufacturing Inventories Really Decreased? An Empirical Study, Manufacturing and Service Operations Management, 3(1), 2001, 14-24.

9. $\quad$ Schonberger, R.J., The Right Stuff, Revisited, MSI, 21(9), 2003, 26.

10. Sheffi, Y. Supply Chain Management Under the Threat of International Terrorism, International Journal of Logistics Management, 12(2), 2001, 1-11.

11. Vastag, G. \& Whybark, D.C., Inventory Management: Is There a Knock-On Effect? International Journal of Production Economics, 93, 2005, 129.

12. Vergin, R.C., An Examination of Inventory Turnover in the Fortune 500 Industrial Companies, Production and Inventory Management Journal, 39(1), 1998, 51-56. 
NOTES 